\title{
Remedies for Human Rights Violations Caused by Climate Change
}

\author{
Margaretha Wewerinke-Singh \\ Grotius Centre for International Legal Studies, Leiden University, \\ and Pacific Centre for Environment and Sustainable Development, \\ University of the South Pacific \\ m.j.wewerinke@law.leidenuniv.nl
}

\begin{abstract}
The right to a remedy is central to a human rights approach to climate change. However, a range of obstacles inhibit access to justice for victims of human rights violations caused by climate change. This article considers two elements of the right to a remedy: access to justice and substantive redress. In relation to access to justice, it considers the potential of domestic courts, as well as regional and international bodies, to offer redress for human rights violations caused by climate change. In relation to substantive redress, it examines international jurisprudence on remedies and discusses its applicability in the context of climate change. Together, these discussions provide an insight into the obstacles to justice for human rights violations caused by climate change and the ways in which these may be overcome.
\end{abstract}

\section{Keywords}

climate justice - right to a remedy - climate litigation - access to justice - human rights

1

\section{Introduction}

'If you keep animals you are to find food for them, and for us that is hay. And even if you plan to work every day at the hay, the weather keeps you 
from it. Every day it is raining. The land is going under water, and the hay lands are smaller and smaller.'

—ELDER from Siberia

'We face more and more extreme heat in our region. ... Water is missing for herding and drinking - most importantly, my children's health is in danger. They suffer because of these extreme heatwaves that we have been facing for some years now. ${ }^{2}$

— RовA GUYo, Herder from Northern Kenya

'Now of course the issue of relocation and resettlement is a very, very serious issue that we are continuing to investigate, but we do not want to leave our land. ... I understand that the issue of litigation has been looked at. We are not going to go quietly. There are human rights issues; there are sovereign rights issues that need to be looked at carefully. ${ }^{3}$

- AMBASSADOR of a Pacific Island state

Redress for injury is central to a human rights approach to climate change, and indeed is a basic axiom of justice. ${ }^{4}$ As Justice Guha Roy has pointed out, social life is 'unthinkable' without the timeless premise 'That a wrong done to an individual must be redressed by the offender himself or by someone else against whom the sanction of the community may be directed. ${ }^{5}$ Shelton observes that remedies are 'not only about making the victim whole; they express opprobrium to the wrongdoer from the perspective of society as a whole' and thus 'affirm, reinforce, and reify the fundamental values of society' ${ }^{6}$

1 Susan A. Crate, 'Gone the Bull of Winter?', 49(4) Current Anthropology 569-595 (2008), at 578 .

2 The People's Climate Case: Quotes from the Plaintiff Families and Supporting NGos, <https:// peoplesclimatecase.caneurope.org/wp-content/uploads/2018/05/quotes-from-plaintifffamilies-2.pdf>.

3 Karen E. McNamara and Chris Gibson, "We Do Not Want to Leave our Land": Pacific Ambassadors at the United Nations Resist the Category of "Climate Refugees"', 40(3) Geoforum 475 (2009), at 481.

4 Parts of this article draw on Margaretha Wewerinke-Singh, State Responsibility, Climate Change and Human Rights under International Law (Oxford, UK: Hart Publishing, 2019).

5 Justice Roy, 'Is the Law of Responsibility of States for Injuries to Aliens a Part of Universal International Law?', 55 American Journal of International Law 863 (1961).

6 Dinah Shelton, 'The Right to Reparations for Acts of Torture: What Right, What Remedies?', 17(2) Torture 96 (2007), at 96. 
In international human rights law, the right to a remedy is a substantive right that is well-established through both custom ${ }^{7}$ and treaties. The European Court of Human Rights (ECtHR) has emphasized that the purpose of human rights law is '[to guarantee] not rights that are theoretical or illusory but rights that are practical and effective., ${ }^{8}$ Similarly, the African Commission on Human and Peoples' Rights has stressed that 'The rights and freedoms of individuals enshrined in the [African] Charter can only be fully realized if governments provide structures which enable them to seek redress if they are violated' ${ }^{9}$ The right is embedded in the general law of state responsibility, which stipulates the components and consequences of internationally wrongful conduct. ${ }^{10}$

Increasing recognition of the threats posed by climate change to the enjoyment of human rights confirms the importance of the right to a remedy for human rights violations associated with climate change." The question of how conduct contributing to or exacerbating the effects of climate change can amount to a violation of international human rights law has been discussed in detail elsewhere, ${ }^{12}$ and will not be addressed in detail here. This article proceeds on the assumption that conduct that contributes to climate change can, at least in some cases, amount to a violation of a state's human rights obligations. In structure, the article mirrors the two elements of the right to a remedy that are guaranteed in most human rights treaties: access to justice and

See Basic Principles and Guidelines on the Right to a Remedy and Reparation for Victims of Gross Violations of International Human Rights Law and Serious Violations of International Humanitarian Law, UNGA Res. 6o/147 of 16 Dec. 2005, Annex, Principles 1(b), 2, 3 and (pertaining to gross violations of international human rights law and international crimes) 11. See also Moiwana Village v. Surinama, (2005), 124 Inter-American Court of Human Rights (ser. C) para. 169. See further Dinah Shelton, Remedies in International Human Rights Law (Oxford, UK: Oxford University Press, 2nd ed., 2010), at 103.

See, for example, Airey v. Republic of Ireland (1979) Series A no 32, 2 E HRR, 305. See also, Stephen Humphreys, 'Introduction: Human Rights and Climate Change', in Stephen Humphreys (ed.), Human Rights and Climate Change (Cambridge, UK: Cambridge University Press, 2010), at 11.

9 Jawara v. The Gambia Communications 147/95, 149/96 74 .

10 While there has been debate about the possibility of human rights law being a so-called self-contained regime that excludes the application of the general law on state responsibility, the prevailing view is that this is not the case. See e.g. Human Rights Committee, General Comment 31, para. 2. See also Ilias Bantekas and Lutz Oette, International Human Rights Law and Practice (Cambridge, UK: Cambridge University Press, 2nd ed., 2013), at 92.

11 As discussed in other contributions to this special issue.

12 See Margaretha Wewerinke-Singh, supra note 4, chapters 2-7. 
substantive redress. ${ }^{13}$ Access to justice refers to the process of hearing and deciding claims of human rights violation, while substantive redress concerns the result of that process: the actual relief granted to the victim of a human rights violation. ${ }^{14}$ The article considers obstacles to access to justice and substantive redress for victims of climate change-related human rights violations, ${ }^{15}$ and offers proposals on how they may be overcome.

Victims of human rights violations-including those associated with climate change-are entitled to access remedial institutions and procedures affording them a fair hearing and, ultimately, substantive redress. The importance of access to independent judicial or quasi-judicial bodies that can adjudicate human rights violations is such that the element of enforceability is sometimes included in the notion of legal rights. ${ }^{16}$ Without this element, the obligations of states are all too easily mischaracterized as voluntary commitments that may be upheld or disregarded at will. ${ }^{17}$ In the context of climate change, the enforceability of rights is perhaps their greatest distinguishing factor as compared to other ethical approaches. Below, two types of procedural remedies are discussed: remedies at the domestic level, and remedies at the regional and international level.

\section{$2.1 \quad$ Domestic Remedies}

Under international human rights law, the obligation to ensure a victim's right to a remedy rests squarely on states. The most comprehensive treaty provisions on remedies are found in the International Covenant on Civil and Political Rights, ${ }^{18}$ which protects the right to a remedy in three separate articles.

13 For an overview of global and regional human rights treaties that incorporate the right to a remedy see Shelton, supra note 7 , at 113-20. See also, James Crawford, The International Law Commission's Articles on State Responsibility: Introduction, Text, Commentaries (Cambridge, UK: Cambridge University Press, 2013), at 95, paras 3-4.

14 Shelton, supra note 7 , at 7.

15 The terms 'victims' and 'violations' should be understood as including actual and alleged victims and violations, unless the context indicates otherwise.

16 Morris Ginsberg, On Justice in Society (Ithaca, New York: Cornell University Press, 1965), at 74 .

17 Shelton, supra note 6 , at 98.

18 International Covenant on Civil and Political Rights (adopted 16 December 1966, entered into force 23 March 1976) 999 UNTS 171. 
The broadest of these is Article 2(3), which spells out the obligations of state parties to the Covenant to ensure that any person whose rights are violated is to have an effective and enforceable remedy. ${ }^{19}$ The Human Rights Committee has stipulated that state parties must give effect to this provision by 'establish[ing] appropriate judicial and administrative mechanisms for addressing claims of human rights violations under domestic law'. ${ }^{20}$ It has also found that 'A failure by a State Party to investigate allegations of violations could in and of itself give rise to a separate breach of the Covenant.'. ${ }^{21}$ Based on a comparison of international instruments and practice, Shelton observes that the procedural attributes of the right to a remedy include 'the ability to invoke the guaranteed right, procedural fairness, the capability of the remedial body to afford redress, and effectiveness in fact.'22

Human rights violations associated with climate change present several barriers to justice. First, the greatest burden of climate harm falls on the global poor - those who did the least to cause it. The cost of legal counsel is therefore often an insurmountable obstacle to justice for climate harm. While domestic law sometimes allows for the recovery of costs in public-interest cases, ${ }^{23}$ not all jurisdictions have such provisions and not all rights-based climate cases will qualify as public-interest cases. In some (but not all) jurisdictions, an additional financial challenge is the principle that costs follow the judgment, exposing plaintiffs to the risk of an adverse cost order against them. ${ }^{24}$ Second, due to the scientific and legal complexity of climate change, not all victims will be aware of the possibility of pursuing litigation to seek redress for climate harm. Especially communities in remote areas without access to higher education are unlikely to be fully aware of their legal rights in connection with climate damages suffered. ${ }^{25}$ Third, nearly every imaginable rights-based

19 ICCPR article 2(3)(c). For a discussion of the evolution of the Human Rights Committee's position on the right to a remedy see generally Martin Scheinin, 'The Human Rights Committee's Pronouncements on the Right to an Effective Remedy: An Illustration of the Legal Nature of the Committee's Work under the Optional Protocol', in Nisuke Ando (ed.), Towards Implementing Universal Human Rights (Leiden: Martinus Nijhoff, 2004), esp. at 101-3. See also, Shelton, supra note 7 , at 50 .

$20 \quad$ General Comment No. 31 para. 15.

21 Ibid para. 15.

22 Shelton, supra note 6, at 109.

23 Shelton, supra note 7 , at 23.

24 See also Helen Duffy, Strategic Human Rights Litigation: Understanding and Maximising Impact (Oxford, UK: Hart Publishing, 2018), at 27.

25 For an illustration see Iqbal Kabir, et al., 'Knowledge and Perception about Climate Change and Human Health: Findings from a Baseline Survey among Vulnerable Communities in Bangladesh', 16 BMC Public Health 266 (2016). 
climate case before a domestic court will need to overcome legal obstacles relating to standing, causation, attribution, and the discernment of environmental standards in abstract human rights provisions. Finally, victims located in low-emitting states face specific challenges in identifying defendants, and, where a case is brought before their domestic courts, asserting jurisdiction over those defendants and enforcing judgements. Where litigation is pursued in a state other than that of the victims, they face the challenge of navigating the rules of unfamiliar jurisdictions, including rules relating to costs, and may not be eligible for legal aid in those jurisdictions. The right to a remedy requires states to take legislative measures to address this range of obstacles head-on.

Access to justice for human rights violations associated with climate change is gaining renewed importance in the context of what Peel and Osofsky have called 'a rights turn in climate litigation'. ${ }^{26}$ Nearly twenty rights-based climate cases have now been brought before domestic courts. The cases of Leghariv. Federation of Pakistan ${ }^{27}$ and Urgenda v. The Netherlands ${ }^{28}$ provide early illustrations of the ability of domestic courts to grapple with the human rights dimension of climate change. However, neither of these cases addressed the transboundary nature of climate-related human rights violations: the focus in both was on the state's obligations vis-à-vis its own citizens. Moreover, neither of the cases involved a reparation claim. It remains to be seen to what extent domestic courts are prepared to give effect to the right to a remedy in cases where the plaintiffs are based outside the state's territory, and to what extent courts will award reparations for climate-change-related human rights violations.

\subsection{Remedies at the Regional and International Levels}

Where domestic remedies are not available, or available remedies are ineffective or inadequate, victims of climate change may be able to access regional or international human rights bodies. ${ }^{29}$ The most detailed procedures for hearing complaints from victims of human rights violations are those established at the regional level: the ECtHR; the African Commission on Human and Peoples' Rights (ACHPR) and African Court on Human and Peoples' Rights

\footnotetext{
26 Jacqueline Peel and Hari M. Osofsky, 'A Rights Turn in Climate Litigation?', 7(1) Transnational Environmental Law 37 (2018).

27 [2015] W.P. No. 25501/201, Lahore High Court, 4 April 2015.

28 C/og/456689/HA ZA 13-1396, The Hague Court of Appeal, Civil-law Division, 9 October 2018.

29 Antonio A. Cancado Trindade, The Application of the Rule of Exhaustion of Local Remedies in International Law (Cambridge, UK: Cambridge University Press, 1983) 1, 57. See also Shelton, supra note 7 , at 114 .
} 
(ACtHPR); and the Inter-American Court of Human Rights (IACtHR) and Inter-American Commission on Human Rights (IACHR). Each of these has dealt with a significant number of cases concerning human rights violations resulting from environmental harm. Most human rights treaty bodies at the international level have also indicated in their General Comments and observations on states' reports that harm resulting from climate change falls within the scope of their respective mandates. ${ }^{30}$ The IACHR remains the only regional human rights body to have received individual complaints about human rights violations resulting from climate change. ${ }^{31}$ The first (and so far only) climate case before an international human rights body was recently brought before the UN Human Rights Committee. ${ }^{32}$

When considering the role of regional and international human rights bodies in providing access to justice for human rights violations relating to climate change, a first point to note concerns the limitations of the mandates of some of those bodies as far as remedies are concerned. The mandate of the IACtHR contained in Article 63(1) of the Inter-American Convention on Human Rights is one of the most comprehensive, providing that, upon establishing a violation, the Court 'shall rule that the injured party be ensured the enjoyment of his right or freedom that was violated' and, 'if appropriate, that the consequences of the measure or situation that constituted the breach of such right or freedom be remedied and that fair compensation be paid to the injured party'.33 The Inter-American system thus 'leads the way in its approach to creative, holistic and case-specific reparation' ${ }^{34}$ The African Court of Human Rights has a similarly broad mandate: it 'shall', upon finding a violation of a Charter right,

30 For an overview see Center for International Environmental Law and The Global Initiative for Economic, Social and Cultural Rights, 'States' Human Rights Obligations in the Context of Climate Change: 2019 Update', <https://statici.squarespace.com/ static/5a6eo958f6576ebdeoe $78 \mathrm{c18} / \mathrm{t} / 5$ c99f5c8652dea22o23bo3b4/1553593972745/HRTB+F eb.+2019+update+-+2019-03-25.pdf>.

31 The Inuit Petition; and Petition to the Inter-American Commission on Human Rights Seeking Relief from Violations of the Rights of Arctic Athabaskan Peoples Resulting from Rapid Arctic Warming and Melting Caused by Emissions of Black Carbon by Canada (2013), <http://earthjustice.org/sites/default/files/AAC_PETITION_13-04-23a.pdf >. For an assessment of the impact of the Inuit petition see Sébastien Jodoin, Shannon Snow, and Arielle Corobow, Realizing the Right to Be Cold? Tracing the Impact of the 2005 Inuit Petition on Human Rights and Climate Justice' (forthcoming).

32 Katharine Murphy, 'Torrest Strait Islanders Take Climate Change Complaint to the United Nations', The Guardian, 12 May 2019.

33 Inter-American Convention on Human Rights, article 63(1).

34 Duffy, supra note 24 , at 33 . 
'make appropriate orders to remedy the violation, including the payment of fair compensation or reparation'. ${ }^{35}$ The jurisprudence from the African human rights system stands out for its recognition of victims' entitlement to collective remedies. ${ }^{36}$ The mandate of the ECtHR is more limited, with Article 41 of the Convention providing that

If the Court finds that there has been a violation of the Convention or the protocols thereto, and if the internal law of the High Contracting Party concerned allows only partial reparation to be made, the Court shall, if necessary, afford just satisfaction to the injured party.

This provides the Court with the discretion to award just satisfaction. The Court's case law on what constitutes necessity remains unpredictable. ${ }^{37}$ If the Court does decide to use its discretion to afford just satisfaction, it is usually in the form of monetary compensation. Finally, the greatest limitation of the international human rights system is the non-binding nature of treaty bodies' decisions on the merits of complaints; a limitation that also applies to the ACHPR and IACHR. ${ }^{38}$

The hurdles facing plaintiffs in rights-based climate cases at the regional and international level resemble the hurdles facing plaintiffs in other forms of climate litigation (e.g. actions in delict or tort) but are distinct from those claims because of the specific international human rights context in which they arise.

First, plaintiffs must establish that they are the victim of the alleged human rights violation associated with climate change. The designation of a 'victim' includes at least those individuals whose rights have been violated, and may include a victim's descendants (where the victim is deceased) ${ }^{39}$ or

35 Ibid.

36 Duffy, supra note 24 , at 33 .

37 Antoine Buyse, 'Lost and Regained? Restitution as a Remedy for Human Rights Violations in the Context of International Law', 68 HeidelbergJournal of International Law 129 (2008), at 147 .

38 See, further, Jane Connors and Markus Schmidt, 'United Nations', in Daniel Moeckli, et al., International Human Rights Law (Oxford, UK: Oxford University Press, 2nd ed., 2014), at 383 .

39 E.g. Comm. No. 107/1981, Quinteros v. Uruguay, UN GAOR, Hum.Rts.Comm., 38th Sess., Supp. No. 40, at 216, UN Doc. A/38/40 (1983), para. 14; Bleier v. Uruguay, Comm. No. 30/1978, Hum. Rts. Comm., 37th Sess., UN GaOr Supp. No. 40 at 130, UN Doc. A/37/40, Annex X (1982). 
third parties affected by the violation..$^{40}$ While there is, as yet, no human rights jurisprudence that sheds light on the question of victimhood in the context of climate change, the ECtHR emphasized in a case brought by an association established to defend its members' interests against the consequences of the construction of a dam that "the term "victim" ... must be interpreted in an evolutive manner in the light of conditions in contemporary society. ... [An] excessively formalistic ... interpretation of that concept would make protection of the rights guaranteed by the Convention ineffectual and illusory'.41 This interpretation presses in favour of allowing those whose rights are violated as a result of climate change, as well as their descendants and possibly even collective bodies representing their interests to act as plaintiffs in proceedings before regional or international human rights bodies.

A related requirement is that the plaintiff must establish that the regional or international body in question has jurisdiction over the case. To meet this requirement, the plaintiff does not need to be a national or resident of the defendant state ${ }^{42}$ but must make out a prima facie case that his or her human rights are violated as a result of activities over which the defendant state had control. ${ }^{43}$ In cases relating to climate change, this will involve providing evidence of a causal link between the state's climate laws, policies, or practices and a harm suffered by the plaintiff. Establishing such specific causation can be daunting for plaintiffs, bearing in mind that data and statistics about climate impacts are often weak or lacking in the areas where populations are most at risk. ${ }^{44}$ The evidentiary burden on plaintiffs could be eased through an approach based on the precautionary principle, which prohibits the use of scientific uncertainty as an excuse to proceed with a risky development. ${ }^{45}$ This approach has been applied by the ECtHR in numerous environmental cases ${ }^{46}$ and could form the basis for a 'probabilistic' approach to causation in climate change cases. ${ }^{47}$ Adopting such an approach to causation seems indispensable

40 E.g. Colozza and Rubinat v. Italy (1985) 89 Eur.Ct.H.R. (ser. A).

41 Gorraiz Lizarraga and others $v$. Spain, paras 37-39.

42 E.g. case 186/87, Cowan v. Tresor Public [1989] ICR 195.

43 E.g. IACtHR, Advisory Opinion on the Environment and Human Rights, para. 103, 104(h).

44 UN-desa, 'Data and Statistics for Climate Change Resilience', UN Desa Policy Brief no. 49 (September 2016) available at <www.un.org/development/desa/dpad/wp-content/ uploads/sites/45/post/WESS2016-PB6.pdf>.

45 For a discussion see Lydia Omuko, 'Applying the Precautionary Principle to Address the "Proof Problem" in Climate Change Litigation', 12(1) Tilburg Law Review (2016) 55.

46 See, e.g., Tatarv. Roumanie App no 67021/01 (ECtHR, 5 July 2007).

47 Omuko, supra note 45 . 
to guaranteeing the right to a remedy for victims of human rights violations that result from climate change.

Second, plaintiffs who bring a case before an international human rights body must demonstrate that all relevant remedies available at the domestic level have been exhausted..$^{48}$ In practice, this usually means that the case must have been pursued through the local court system. ${ }^{49}$ However, the requirement of exhaustion of domestic remedies can be met in cases where the remedies are unavailable or clearly ineffective. In climate change cases, plaintiffs in low-emitting states may be able to argue that effective domestic remedies are not available to them because the state in which they reside has little or no control over the entities that are mostly responsible for greenhouse gas emissions. Additionally, or alternatively, plaintiffs in developing states may point to those states' relatively minor historical contributions to climate change and their correspondingly minor responsibility for compensating victims. Finally, where a state is unwilling or unable to provide victims of climate-changeinduced human rights violations with legal aid to pursue domestic remedies that are technically available, those remedies may be considered exhausted even if they have not in fact been pursued. ${ }^{50}$

Lastly, claims before regional and international human rights bodies will only be admissible if the defendant state is a party to both the treaty containing the relevant rights and, where relevant, the treaty establishing the complaint mechanism. The facts constituting the basis for the claim must have occurred after the entry into force of those treaties. However, an exception can be made in cases where the violation of the treaty is ongoing. ${ }^{51}$ In cases where a state's failure to adequately regulate emissions is the basis for the claim, the start of the violation likely predated the entry into force of the relevant

48 But note that in the Inter-American human rights system the burden of proving the existence of a domestic remedy and the failure to exhaust it is on the respondent government. See Martin Wagner and Donald M. Goldberg, 'An Inuit Petition to the Inter-American Commission on Human Rights for Dangerous Impacts of Climate Change', paper presented at COP 10, UNFCCC, 15 December 2004, <www.ciel.org/Publications/COP10_Handout_EJCIEL.pdf $>$.

49 This is the case, for example, in Plan B Earth and Others v. Secretary of State for Business, Energy and Industrial Strategy, 2017, Claim No. CO/16/2018 (UK).

$50 \quad$ See, e.g., Human Rights Committee, Quelch v. Jamaica, Communication No 292/1988, views of 23 October 1992, UN Doc. CCPR/46/D/292/1988, para. 8.2; Human Rights Committee, Henryv. Jamaica, Communication no. 230/1987, views of 1 November 1991, UN Doc. CCPR/C/43/D/230/1987, para. 7.3.

51 See, e.g., Jom Pasqualucci, The Practice and Procedure of the Inter-American Court of Human Rights (Cambridge, UK: Cambridge University Press, 2nd ed., 2003), at $138 \mathrm{ff.}$ 
treaties for that state. Still, the ongoing nature of the alleged violation may bring it within the ratione temporis of the treaty body's jurisdiction.

\subsection{Inter-state Complaints}

The law of state responsibility complements human rights law on access to justice in some important ways. Above all, it entitles states to invoke the responsibility of other states that violate their obligations under international human rights law because of action or inaction relating to climate change. The law of state responsibility also underpins the entitlement of states to seek redress for human rights violations on behalf of victims through relevant international forums. In principle, states are expected to use the special bodies and courts set up to monitor compliance with human rights obligations, unless the remedy provided by these bodies 'would be manifestly unavailable or ineffective or where it would be otherwise unreasonable to expect recourse to it.' ${ }^{52}$ In such cases, states may pursue a claim before the International Court of Justice (provided that the conditions for jurisdiction are satisfied), ${ }^{53}$ or even resort to the use of proportionate counter-measures. ${ }^{54}$

Inter-state cases for human rights violations are rarely pursued in practice. This may be explained by a perceived lack of direct injury to states, ${ }^{55}$ and a general preference for diplomatic forms of dispute resolution. This may change as a result of worsening loss and damage from climate change, and the perceived exhaustion of negotiations as a way to force meaningful action on loss and damage from climate change.

\section{3}

Substantive Redress

The law on remedies for human rights violations reflects the general law on state responsibility. This general law is premised on the principle that a state

$5^{2}$ Report of the Study Group of the ILC, Fragmentation of International Law: Difficulties Arising from the Diversification and Expansion of International Law, UN Doc. A/CN.4/L.682 (13 April 2006), para. $15^{2}$.

53 See, further, Margaretha Wewerinke-Singh and Diana Salili, 'Negotiations or Litigation: Vanuatu's Perspective on Loss and Damage from Climate Change', Climate Policy (forthcoming).

54 See arts 49-55 ARSIWA and the discussion in ILC, supra note 52, paras 123-94.

55 Most interstate cases concerning human rights violations involved nationals of the complaining state. See e.g. Interstate Case 01/6, Nicaragua v. Costa Rica, 8 March 2007, Reports no. 11/97; D.R. Congo v. Burundi, Rwanda, Uganda, Comm. 227/1999, Twentieth Activity Report of the African Commission on Human and Peoples' Rights, Annex IV, p. 96; Georgia v. Russia, ECtHR, no. $38263 / 08$. 
that violates its obligations under international law must 'must, so far as possible, wipe-out all the consequences of the illegal act and re-establish the situation which would, in all probability, have existed had that act not been committed. ${ }^{56} \mathrm{~A}$ key point to note is that these new obligations arise automatically when a state breaches its legal obligations under international human rights law. In other words, the legal consequences of human rights violations are not affected by the limitations on human rights bodies' power and mandate that were highlighted above. The substantive legal consequences of a human rights violation —obligations of cessation and reparation—are discussed below.

\subsection{Cessation of Unlawful Conduct and Guarantees of Non-repetition}

The International Law Commission's Articles on State Responsibility clarify that a state that violates its international obligations must continue to perform its original obligations ${ }^{57}$ and cease the wrongful conduct (if it is ongoing). ${ }^{58}$ Paragraph (b) of Article 30 (which deals with the duty of cessation) further articulates an obligation to offer appropriate assurances and guarantees of non-repetition where circumstances require. ${ }^{99}$ The Human Rights Committee recognizes the duty of cessation as 'an essential element of the human right to a remedy'; it entails an obligation 'to take measures to prevent the recurrence of a violation', including through changes in the state party's laws or practice, if necessary. ${ }^{60}$

Where the violation results from a state's failure to prevent the negative human rights impacts of climate change, the duty to offer appropriate assurances and guarantees of non-repetition could entail an obligation to adopt and implement enforceable legislation to protect human rights from future climate impacts. In these cases, the court's judgement on the merits will likely have grappled with the question of what levels of emission reductions are required of states to achieve the required protection of human rights. In Urgenda, the Hague Court of Appeal found that this question needs to be answered based on the best available scientific evidence about the damages resulting from climate change; the risks of dangerous climate change; the technical possibilities for precautionary measures; and the estimated costs

\footnotetext{
56 Case Concerning the Factory at Chorzów (Germany v. Poland) 47.

57 ILC ARS, art. 29.

$5^{8}$ ILC ARS, art. 30(a). See also, Crawford, supra note 13, at 68, para. 114.

59 ILC ARS, art. $30(\mathrm{~b})$ and Commentary to Article 30, para. 1.

6o HRC, General Comment No. 31, paras 16-17.
} 
and benefits of such measures. ${ }^{61}$ In cases brought by victims of human rights violations resulting from climate change, victims' testimonies about their lived experiences with climate risk and harm could also inform the court's reasoning on the content of a state's prevention obligations. Guarantees of non-repetition would need to be tailored towards preventing the continuation or reoccurrence of the specific acts and omissions that were found to violate the state's obligations to protect human rights against the impacts of climate change.

\subsection{Reparations for Victims}

A distinct obligation triggered by a human rights violation is the obligation to make full reparation for the injury caused by the wrongful act. ${ }^{62}$ This obligation is 'without prejudice to any right, arising from the international responsibility of a State, which may accrue directly to any person or entity other than a State.63 In case of a human rights violation, the obligation may be owed to the international community as a whole by virtue of the erga omnes nature of human rights violations. ${ }^{64}$ However, the ultimate holders of a right to 'full reparations' are the beneficiaries of the human rights obligations that were violated. ${ }^{65}$ The entitlement to reparations is conditional on a causal connection between the injury and the internationally wrongful act. In the context of human rights violations, the causality test must be derived from international human rights law. ${ }^{66}$ Here, the principle of in dubio pro libertate et dignitate could be applied — namely that where there is doubt as to the meaning of a treaty provision, its interpretation must favour the protection of human rights. ${ }^{67}$ Applying this principle in the context of climate change could allow judicial or quasi-judicial bodies to find in favour of a victim where the link between a state's conduct and the harm to the victim cannot be established

61 C/og/456689/HA ZA 13-1396, The Hague Court of Appeal, Civil-law Division, 9 October 2018, paras 4.63 and 4.86 .

62 ILC ARS, art. 31(1).

63 Ibid. See also, HRC, General Comment No. 31, para. 16. Sergio Euben Lopez Burgos v. Uruguay, para. 14.

64 ILC ARS, art. 33(1).

65 See also, HRC, General Comment No. 31, para. 16. Sergio Euben Lopez Burgos v. Uruguay, para. 14.

66 This follows from ILC ARs, Commentary to article 31, para. 10.

67 Manfred Nowak, Introduction to the International Human Rights Regime (Leiden: Martinus Nijhoff, 2003), at 65-6. 
with certainty. A similar effect could be achieved by applying the precautionary principle. ${ }^{68}$

In rights-based climate cases, shifting the burden of uncertainty from plaintiffs to state defendants helps to safeguard procedural fairness. At the same time, accepting that millions of victims may be entitled to reparations for human rights violations related to climate change triggers a new question: how should responsibility for reparations be apportioned between states, including in cases where the responsibility of multiple states is invoked at once? This question takes us into unchartered territory in international human rights law, ${ }^{69}$ and raises a number of legal and evidentiary complexities. ${ }^{70}$ One approach to this question is to allocate responsibility for reparations according to states' respective contributions to historical emissions. This approach is currently being tested in Lliuya v. $R W E,{ }^{71}$ where the petitioner is seeking contributions to reparations proportionate to the defendant's contributions to historical greenhouse gas emissions. ${ }^{72}$ The plaintiff has submitted evidence demonstrating that this contribution amounted to 0.47 per cent of the global total. To replicate this approach in cases against states, data is needed on states' respective contributions to historical greenhouse gas emissions. While there are reliable data on Annex I emissions from $1990,{ }^{73}$ the data on non-Annex I emissions and pre-1990 data for all states suffers from holes and uncertainties. However, data are available on states' respective historical per capita and gross $\mathrm{CO}_{2}$ emissions since $1750 .{ }^{74}$ Courts confronted with reparations claims in climate cases would need to grapple with these limitations in available data.

68 See, further, Dinah Shelton, 'Complexities and Uncertainties in Matters of Human Rights and the Environment: Identifying the Judicial Role', in John H. Knox and Ramin Pejan, The Human Right to a Healthy Environment (Cambridge, UK: Cambridge University Press, 2018), at 113-17.

69 But see André Nollkaemper and Ilias Plakokefalos (eds.), The Practice of Shared Responsibility in International Law (Cambridge, UK: Cambridge University Press, 2017).

70 See, e.g., John Knox, Report on the Issue of Human Rights Obligations Relating to the Enjoyment of a Safe, Clean, Healthy and Sustainable Environment, UN Doc. A/HRC/31/52 (2016), para. 35 .

71 Case no. 2 285/15, District Court Essen, 15 December 2016.

72 Lliuya v. RWE, 'Facts of the Case' (unpaginated transcript).

73 Jacqueline Peel, 'The Practice of Shared Responsibility in Relation to Climate Change', (2015) 71 Shares Research Paper 1, 31.

74 Tim Crosland, Aubrey Meyer, and Margaretha Wewerinke-Singh, "The Paris Agreement Implementation Blueprint: A Practical Guide to Bridging the Gap between Actions and Goal and Closing the Accountability Deficit (Part 1)', 25(2) Environmental Liability 114 (2017). 
Moreover, reparation claims premised on international law, including human rights law, trigger questions about retrospectivity: only injury caused by acts that were wrongful at the time they were committed trigger secondary obligations to make full reparations. The implication is that past emissions will only count towards a state's responsibility for reparations from the date 'when they became cumulatively wrongful'. ${ }^{75}$ Pinpointing this date will require an assessment of a state's legal obligations over time as well as the foreseeability of climate change and its adverse effects. States' legal obligations under international human rights law over time will depend on their exact record of ratifying human rights treaties, and on the evolution of specific human rights into norms of customary international law. The date when climate change and its adverse effects became foreseeable will likely be somewhere between 1827 , when the first scientific study demonstrated a relationship between the emission of greenhouse gases and warming of the atmosphere, and the publication of the IPCC's first assessment report in $1990 .{ }^{76}$

An approach that might, at least initially, circumvent these questions about evidence and retrospectivity is reliance on the principle of joint and several liability, according to which any of multiple tortfeasors may be held liable for the entire damage irrespective of its own contribution. ${ }^{77}$ However, commentators have identified a range of obstacles in transplanting this doctrine into international law. ${ }^{78}$ Moreover, if a state would indeed be held liable under this doctrine it would be entitled to recover the excess incurred sum from all other states that are responsible for the harm. This illustrates that the complex legal and evidentiary outlined above will inevitably come up in rights-based climate cases that involve reparation claims. This remains an underdeveloped topic in international law scholarship generally, and would benefit from focused attention through the lens of human rights given the potential implications of any apportionment arrangement or limitation on liability for the realization of human rights. Apportioning responsibility for intangible or non-economic

75 Michael G. Faure and André Nollkaemper, 'International Liability as an Instrument to Prevent and Compensate for Climate Change', 43 Stanford Environmental Law Journal 123 (2007), 171-2.

76 See also Richard S. J. Tol and Roda Verheyen, 'State Responsibility and Compensation for Climate Change Damages: A Legal and Economic Assessment', 32 Energy Policy 1109 (2004) at 1109.

77 Roda Verheyen, Climate Change Damage and International Law: Prevention Duties and State Responsibility (Leiden: Martinus Nijhoff, 2005), at 270.

78 See, e.g., Ottavio Quirico, 'Climate Change and State Responsibility for Human Rights Violations: Causation and Imputation', 65(2) Netherlands International Law Review 185 (2018), 200. 
loss and damage resulting from climate change also merits further attention in human rights scholarship.

Concerning the content of reparations, the ILC ARS broadly distinguishes three forms of reparations: restitution in kind (restitution in integrum), compensation, and satisfaction, separately or in combination..$^{79}$ Each of these is discussed below.

\subsubsection{Restitution}

As a matter of legal principle, restitution is the primary remedy for violations of international law..$^{80}$ Restitution is required where (a) it is not materially impossible; and (b) it does not involve a burden out of all proportion to the benefit deriving from restitution instead of compensation.81 The Basic Principles and Guidelines on the Right to a Remedy and Reparation for Victims of Gross Violations of International Human Rights Law and Serious Violations of International Humanitarian Law clarify that in the context of gross violations of human rights, restitution can include 'restoration of liberty, enjoyment of human rights, identity, family life and citizenship, return to one's place of residence, restoration of employment and return of property'.22 The IACtHR confirmed in its Velasquez Rodriguez (Compensatory damages) judgement that, in cases of human rights violations, restitution involves 'the restoration of the prior situation, the reparation of the consequences of the violation, and indemnification for patrimonial and non-patrimonial damages, including emotional harm.' ${ }^{83}$ The principle of restitution in integrum has been similarly endorsed in the jurisprudence of the ECtHR ${ }^{84}$ and the African Commission on Human and Peoples' Rights. ${ }^{85}$

In the context of climate change, restitution will sometimes be materially impossible due to the nature of the harm. This is most obviously the case where climate impacts cause loss of life, or where victims incur physical or mental disabilities. In such situations, compensation may need to be awarded.

\footnotetext{
79 ILC ARS, art. 34.

$80 \quad$ ILC ARs, Commentary to Article 36 , para. 3 .

81 ILC ARS, art. 34.

82 Principle 19. These principles were adopted and proclaimed by the UN General Assembly in Resolution 6o/147 (16 December 2005).

83 IACtHR, Velasquez Rodriguez v. Honduras (Compensatory damages), 21 July 1989 (Series C, No. 7 , Case No. 7920) paras 25-6.

84 See, e.g., ECtHR, Barbera, Messegué and Jabardo v. Spain (Article 50), 13 June 1994, Series A no. 285 -C, para. 16 .

85 See Gino J. Naldi, 'Reparations in the Practice of the African Commission on Human and Peoples' Rights', 14 Leiden Journal of International Law 682 (2001), at 685.
} 
In other situations, restitution (or an approximation of it) may be possible, albeit at a high financial cost. In the case of human rights violations resulting from the inundation of an island, for example, building an artificial island may repair at least some of the harm. ${ }^{86}$ The inalienable nature of human rights would favour such action if it indeed restores the enjoyment of rights, even if it poses a significant burden on the responsible state or states.

\subsubsection{Compensation}

Where restitution is unavailable or inadequate, a state is under an obligation to provide compensation for the damage caused by its wrongful act covering 'any financially assessable damage including loss of profits insofar as it is established' ${ }^{87}$ Compensation is limited to damage that is both provable and proximate ${ }^{88}$ At the same time, compensation should be commensurate with the loss, so that the victim 'may be made whole.' 89

In the context of climate change, the monetary value of damages may be relatively straightforward to assess in some cases. For example, victims whose homes were destroyed or damaged as a result of an extreme weather event may be awarded an amount of compensation that enables them to rebuild or repair their home. ${ }^{90}$ In other cases, however, assessing the monetary value of climate-related damage is more difficult. This is the case, for example, where human life is lost, people are physically or mentally injured, cultures and traditional ways of life are undermined, or ecosystems are damaged beyond repair. ${ }^{91}$ The Basic Principles and Guidelines underscore that, irrespective of the nature of the harm, compensation must be 'proportional to the gravity of the violation and the circumstances of each case. ${ }^{92}$ Comparative law and economic theory and practice can provide helpful guidance in the interpretation of the

86 John Vidal, 'Artificial Island Could Be Solution for Rising Pacific Sea Levels', The Guardian, 8 September 2011, <www.theguardian.com/environment/blog/2011/sep/o8/artificial-island -pacific-sea-levels $>$.

$87 \quad$ ILC ARS, art. 36 .

88 Alan Boyle, 'Reparation for Environmental Damage in International Law: Some Preliminary Problems', in Michael Bowman and Alan Boyle (eds), Environmental Damage in International and Comparative Law (Oxford, UK: Oxford University Press, 2002), 16, 24.

89 ILC ARs, Commentary to Article 36, para. 3, quoting 'Lusitania' Cases (United States/ Germany), 7 UNRIAA 32, 39 (1923).

$90 \quad$ ILC ARs, Commentary to Article 36.

91 Nico Schrijver, 'The Impact of Climate Change: Challenges for International Law', in Ulrich Fastenrath and others (eds), From Bilateralism to Community Interests: Essays in Honour of Bruno Simma (Oxford, UK: Oxford University Press, 2011) 1280, 1297. 
notions of proportionality and 'making the victim whole'. ${ }^{93}$ Moreover, there is a wealth of precedents for quantifying damages where these are difficult to quantify, including loss of life, arbitrary detention and other personal injury, and environmental damage. ${ }^{94}$ At the same time, human rights law requires direct engagement with victims to assess the gravity of the violations suffered and to compensate them adequately for losses of 'things that they value, and for which there are no commensurable substitutes' ${ }^{95}$

While compensation can rarely restore the enjoyment of rights that were violated, it can, in Shelton's words, 'supply the means for whatever part of the former life and projects remain possible and may allow for new ones. ${ }^{96}$ The tangible nature of compensation also provides victims with an important affirmation of their rights. At the same time, it ensures that the costs of the violation are born by the defendant rather than the victim, thus providing an incentive to prevent recurrence of the harm. Compensation may therefore contribute to the transition to low-emission societies.

\subsubsection{Satisfaction}

States responsible for an internationally wrongful act are under an obligation to provide measures of satisfaction insofar as the injury 'cannot be made good by restitution or compensation. ${ }^{97}$ Satisfaction may involve 'an acknowledgement of the breach, an expression of regret, a formal apology or another appropriate modality' ${ }^{\prime 8}$ In the context of gross human rights violations, it may also require, amongst other things, fact-finding and full and public disclosure of the truth; punishment of the wrongdoers; and commemorations and tributes to the victims and other acts of rehabilitation. ${ }^{99}$

Satisfaction will often be a key component of remedial justice for human rights violations relating to climate change. First, the dignity and rights of victims of climate change - such as those traumatized by losses to their cultural heritage and traditions ${ }^{100}$ — will rarely be restored by compensation alone.

93 Dinah Shelton, 'Righting Wrongs: Reparations in the Articles on State Responsibility', 96 American Journal of International Law 833 (2002), at 851.

95 Basic Principles, Principle 20.

$96 \quad$ Shelton, supra note 7 , at 291.

97 ILC ARs, art. 37(1).

98 ILC ARs, art. 37(2).

99 Basic Principles and Guidelines, Principle 22 paras b, f and g; ARsıwa Commentaries 250-251.

100 Chie Sakakibara, 'Our Home is Drowning: Inupiat Storytelling and Climate Change in Point Hope, Alaska', 98(4) Geographical Review 456 (2008) at 471. 
Moral repair will be needed, alongside compensation, to address most forms of non-economic losses resulting from climate change. For example, Veland et al. highlight the potential of co-producing knowledge (or 'truth') with affected communities, and ultimately 'story[ing] safe and desirable pathways away from dangerous and unjust outcomes, and toward dignified futures'.101

Second, disclosure of the truth and punishment of wrongdoers serve to address the structural causes of climate change and resulting human rights violations. While these forms of satisfaction have so far not been awarded in rights-based climate cases, the Inuit petition did invite the IACHR to hold a hearing to investigate the plaintiff's claims and prepare a report declaring the United States responsible for violation of its rights. ${ }^{102}$ The IACHR agreed to hold a hearing on the impacts of climate change on the enjoyment of human rights despite rejecting the petition. ${ }^{103} \mathrm{~A}$ more far-reaching form of satisfaction would be the adoption of legislation criminalizing the destruction of large areas of natural environment. ${ }^{104}$ Further research into the potential costs and benefits of such legislation could support judicial decision-making on adequate and effective remedies for human rights violations resulting from climate change.

\section{4}

\section{Conclusion}

As the ECtHR stressed in its Broniowski judgment, international law requires that 'individual and general redress ... go hand in hand.' ${ }^{105}$ In the context of climate change, providing individual and general redress requires not only the highest level of ambition in reducing emissions but also 'urgent support to ramp up adaptation among the most vulnerable populations and ensure compensation for those affected', that is, 'ex-ante social transformations and

101 Siri Veland, et al., 'Narrative Matters for Sustainability: The Transformative Role of Storytelling in Realizing $1.5^{\circ} \mathrm{C}$ Futures', ${ }_{31}^{1}$ Current Opinion in Environmental Sustainability 41 (2018).

102 Petition to the IACHR Seeking Relief from Violations Resulting from Global Warming Caused by Acts and Omissions of the United States' (2005), at 118, <www.ciel.org/Publications/ICC_Petition_7Deco5.pdf >.

103 See Earthjustice Press Release entitled 'Inter-American Commission on Human Rights to Hold Hearing on Global Warming' (6 February 2007), <www.earthjustice.org >.

104 See, e.g., Polly Higgins, Eradicating Ecocide (London, UK: Shepheard-Walwyn Publishers, 2015).

105 ECtHR, Broniowski v. Poland (friendly settlement), 28 September 2005 (Appl. No. 31443/96), para. 36 . 
ex-post reparations.106 In practice, however, a range of jurisdiction-specific obstacles inhibit access to justice for victims of human rights violations resulting from climate change. Some of these obstacles may be overcome through creative lawyering and reliance on legal principles that ensure procedural fairness in rights-based climate cases, most notably the precautionary principle. However, in some, if not all jurisdictions access to justice for human rights violations caused by climate change can only be guaranteed through legislative measures specifically targeted at removing these obstacles. In addition to such measures at the domestic level, solutions grounded in multilateralism are needed to eliminate de facto discrimination in victims' access to justice. There is no need to reinvent the wheel: precedents such as the UN Compensation Commission can be used as a model for a reparations mechanism to address loss and damage resulting from climate change. ${ }^{107}$ Such a mechanism would need to ensure that those whose rights have been violated as a result of climate change are the primary beneficiaries of reparations, and that remedies are tailored towards the restoration of their rights. In the absence of such a mechanism, litigation serves to underscore the inevitability of reparation claims for human rights harm resulting from climate change. The radical promise of 'full reparations' inherent in international law may ultimately inspire states to display greater solidarity towards those whose rights are compromised as a result of climate change, and who will continue to seek new avenues to claim their rights in a changing climate. ${ }^{108}$

106 Petra Tschakert, et al., 'One Thousand Ways to Experience Loss: A Systematic Analysis of Climate-Related Intangible Harm from Around the World', 55 Global Environmental Change 58 (2019), at 69 .

107 See e.g. Maxine Burkett, 'Rehabilitation: A Proposal for a Climate Compensation Mechanism for Small Island States', 13(1) Santa Clara Journal of International Law 81 (2015).

108 The author is grateful for valuable comments from Joanne Scott and Annalisa Savaresi, and for research assistance from Nikita Sinha. 